\title{
Forage mass production and grazing loss of sorghum hybrid in response to the density of the sowing and the spacing between planting lines
}

\author{
Flávia Fernanda Simili², Maria Lúcia Pereira Lima², Andréia Luciane Moreira ${ }^{3}$, Paulo \\ Victória Soares ${ }^{4}$, Luiz Carlos Roma Júnior ${ }^{2}$, Ricardo Andrade Reis ${ }^{5}$
}

\author{
1 Auxílio à pesquisa Fapesp. \\ 2 APTA - Ribeirão Preto, SP - 14.030-670. \\ ${ }^{3}$ APTA - Presidente Prudente, SP - 19.015-970. \\ ${ }^{4}$ Médico Veterinário - Ribeirão Preto, SP - 14.030-670. \\ ${ }^{5}$ Departamento de Zootecnia - UNESP - Jaboticabal , SP - 14.884-900.
}

\begin{abstract}
The objective of this experiment was to evaluate dry matter yield and loss of grazing due to animal trampling in response to sowing density and spacing between lines in the planting. Sorghum hybrid 1P400 was submitted to six treatments, composed of three sowing density combinations (12; 16 and $20 \mathrm{~kg} / \mathrm{ha}$ of seeds) and two spacing between lines $(0.40$ and $0.80 \mathrm{~m})$. Sorghum hybrid $1 \mathrm{P} 400$ was sowed in two seasons, at the end of spring (December $\left.3^{\mathrm{rd}}, 2005\right)$ and the other at the end of summer (March 20 $0^{\text {th }}, 2006$ ). Cultivation strategies influenced plant population in the two experimental seasons. Diameter of the stem in season 1 decreased with density increase, whereas in the second season, interaction between sowing density and spacing was significant. In the first season, $0.40-\mathrm{m}$ spacing promoted greater losses due to grazing stepping, that is, $891 \mathrm{~kg} / \mathrm{ha}$ of DM, whereas in the second season there was no statistical difference. There was no significant difference in forage dry matter yield in sowing densities among the two studied seasons. Dry mater production of sorghum hybrids 1P400 did not increase with the increase of the sowing density in the two sowing seasons, therefore it is recommended $12 \mathrm{~kg} / \mathrm{ha}$ of seeds for the sowing. Sorghum IP400 cultivated in $0.80-\mathrm{m}$ spacing resulted in lower forage loss caused by grazing bovine trampling.
\end{abstract}

Key Words: cattle trampling, Sorghum bicolor $\times$ Sorghum sudanense, summer annual grass, tropical grass

\section{Introduction}

The quantity of seeds used in sowing influences production cost and the number of plants/ha, which in turn directly determines the area productivity. The spacing between the lines also influences plant development, height, stem diameter and loss of grazing due to animal stepping.

The sorghum hybrid ((Sorghum bicolor (L.) Moench $\times$ Sorghum sudanense (Piper) Stapf) has been successfully cultivated in the tropical and subtropical areas due to its higher flexibility during sowing seasons and high productivity potential which makes it able to become forage alternatives to intensify animal production, mainly during feed shortage seasons.

The characteristics of these hybrids include fast establishment and vegetative growth, great rusticity, low soil fertility demand, as well as cutting and grazing management facilities. Results of this combination is already known for a long time in countries such as the United States and Argentina where ruminant production is prominent, and even in southern Brazil, where sorghum hybrids have been used in rotational grazing on summer annual grass for decades (Rodrigues, 2000).

Some experiments conducted in the south of Brazil and other countries ratify that the sorghum hybrid, if sowed during the right seasons, i.e., in the end of spring or summer, and when used in cutting or grazing system, can extend its vegetative growth period, providing high quality forage during autumn and part of the winter (Moraes \& Maraschin, 1988).

Sorghum hybrid 1P 400 has an average height of $1.50 \mathrm{~m}$, and stem vigorous regrowth, which allow many cuttings and grazing cycles provided there is water availability. High forage production, 40-50t/ha of the green mass with high nutritive value forage (16 to $18 \%$ crude protein) in 4 to 6 cuttings is observed in the experiments. It is recommended 13 to $16 \mathrm{~kg} / \mathrm{ha}$ of seed and 0.40 to 0.50 of spacing between sowing lines (Dow Agroscience, 2007). According to Embrapa (2007), sorghum hybrid has to be cultivated using 15 to $20 \mathrm{~kg} / \mathrm{ha}$ of seed and $0.30 \mathrm{~m}$ of distance between rows; whereas Restle et al. (2002) used $30 \mathrm{~kg} / \mathrm{ha}$ of AG2501C hybrid viable seeds, and $0.20 \mathrm{~m}$ of row distance between sowing lines. 
The objective of the experiments was to analyze the dry mass yield and forage loss after grazing caused by animal stepping as a consequence of sowing density and spacing between sowing lines.

\section{Material and Methods}

The experiments were conducted in APTA - Centroleste (Agência Paulista de Tecnologia dos Agronegócios) in Ribeirão Preto - SP. The local soil is Dystroferric Red Latosol (Oxisol) (Embrapa, 1999), previously classified as Dusky-Red Latossol (Oxisol) undulating ground. Sorghum hybrid used in the experiment was the 1P400, launched by the Dow Agrosciences seed company in May 2002.

The experiment was conducted in two seasons: from December 2004 to February 2005, and from March to May, 2006. The statistical analyses were made by PROC GLM (SAS, 2003) in randomized block design, $3 \times 2$ factorial scheme with three plant densities (12, 16 and $20 \mathrm{~kg}$ of seed/ha) and two spacings between lines $(0.40 \mathrm{~m}$ and $0.8 \mathrm{~m}$ ) in a total of six treatments. In the first season, there were two grazing cycles, whereas in the second season, there was only one due to weather conditions. The Tukey test was used to compare the means $(\mathrm{P} \leq 0.05)$.

The statistical analyses were carried out for each season separately, as well as the results and discussion which were also presented separately for each season. Treatments were randomized within each plot $\left(512 \mathrm{~m}^{2}, 12.8 \mathrm{~m}\right.$ width $\times$ $40 \mathrm{~m}$ length) during the different planting dates.

In the first season, the planting date was December $3^{\text {rd }}$ 2004, and in the second season, it was on March $20^{\text {th }} 2006$. A vacuum planter, suitable for no tillage (95\% efficiency), was used to distribute the seeds, and $120 \mathrm{~kg} / \mathrm{ha}$ of the fertilizer 8-28-16+Zn. Before sowing, glyphosate was applied to desiccate the weeds.

The soil analysis showed the following values: $\mathrm{pH} \mathrm{C}_{\mathrm{a}} \mathrm{Cl}_{2}=4.9$; organic matter $=43 \mathrm{~g} / \mathrm{dm}^{3}$; phosphorus in resin $=38 \mathrm{mg} / \mathrm{dm}^{3}$; sum of bases $=48.9 \mathrm{mmol} / \mathrm{dm}^{3}$; base saturation $(\mathrm{V} \%)=51 \% ; \mathrm{CTC}=95.9 \mathrm{mmol} / \mathrm{dm}^{3} ; \mathrm{Ca}=26 \mathrm{mmol} / \mathrm{dm}^{3}$; $\mathrm{K}=3.9 \mathrm{mmol} / \mathrm{dm}^{3} ; \mathrm{Mg}=19 \mathrm{mmol} / \mathrm{dm}^{3}$.

The following variables were analyzed: population of established plants, plant heights, stem diameter, forage dry matter (FDM) before and after grazing, forage loss due to animal stepping when grazing, leaf and stem ratio, dead material, inflorescence before and after grazing.

Plant population (plant/ha) was analyzed by counting the number of plants within $2 \mathrm{~m}$ linear in 10 points per experimental plot. The plant height $(\mathrm{cm})$ was measured by using a ruler graduated in centimeters in 20 sampling points in each experimental plot. In the presence of inflorescence, the reading was performed at the tip of the flag leaf. The plant height after grazing was determined in the stem at the cutting height.

Stem diameter was measured by using a caliper at ground level of $15 \mathrm{~cm}$ (after the first node) in 10 stems, in each experimental plot before grazing.

Forage dry matter (FDM) was determined in sowing lines, before and after grazing. Plants were cut off at ground level: two 2-m long lines and spaced by $0.8-\mathrm{m}$, and three 2 -m long lines, spaced by $0.4 \mathrm{~m}$. There were two samples per experimental plot. Only standing crop samples were considered for the after grazing samples.

Forage loss due to stepping during grazing was analyzed when the after grazing samples were collected. A $1 \mathrm{~m} \times 2 \mathrm{~m}$ rectangle was inserted in the same sampled area and all the material that was overturned by animals was considered loss by trampling. It was necessary to cut down the crops discarding the dead material deposited on the ground, in order to collect only the material of interest. The areas containing feces were discarded. Even though the soil was wet, there was no contamination of the samples (dirt) related to pasture loss.

Leaf, stem, dead material, and inflorescence proportions before and after grazing were established after the samples had been weighed. Two subsamples were made: one to dry the shoot (leaf, stem, dead material, and inflorescence), and the other aiming at the separation into leaves (leaf blades), stems (with sheath), inflorescence and dead material. Afterwards, the samples were oven-dried $\left(65^{\circ} \mathrm{C}, 72\right.$ hours) to reach constant weight. The leaf/stem ratio was obtained by dividing the dry matter of green leaves by the dry matter of green stems.

Grazing was performed on the whole area by crossbred Holstein $\times$ Gir cows with an average weight of $550 \mathrm{~kg}$. In the first season, the animals started the first grazing on January, $11^{\text {th }} 2005$, 34 days after the sowing day, and they were kept in the experimental plot for 2 days; the stocking rate was 2.6 UA/ha with a herbage allowance of 5.94\%. The second grazing started on February $16^{\text {th }}$ 2005, 32 days after the resting period. The animals were kept in the experimental plot for 6 days with a stocking rate of $3.5 \mathrm{UA} / \mathrm{ha}$ with a herbage allowance of $7.53 \%$.

In the second season, rainfall data was very limited (Figure 1). Therefore, it was possible just one grazing cycle on May, $10^{\text {th }}$ 2006, 50 days after the sowing day. The animals were kept in the experimental plot for 5.5 days, with a stocking rate of $2.1 \mathrm{UA} / \mathrm{ha}$ and herbage allowance of $6.80 \%$. 


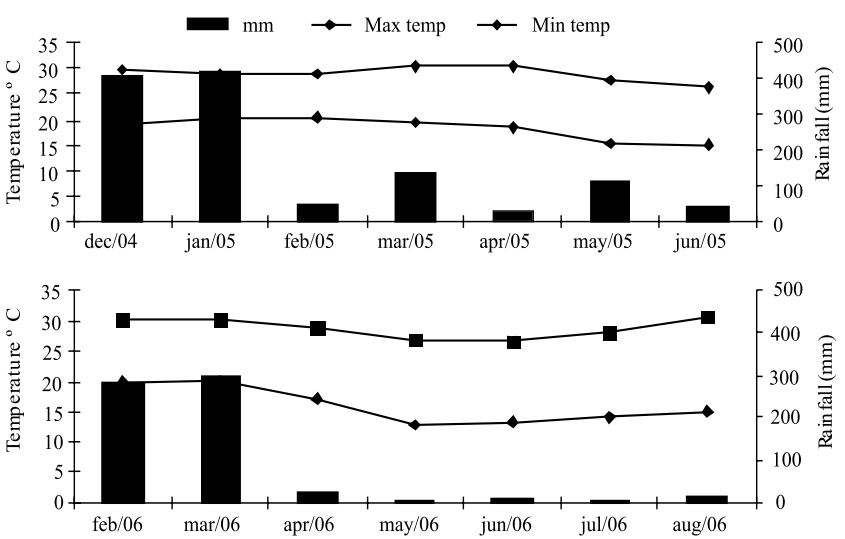

Figure 1 - Rainfall data and maximum and minimum monthly temperatures during the experimental period.

\section{Results and Discussion}

Sowing density and spacing significantly influenced the plant population of sorghum hybrid 1P400 in both sowing seasons inasmuch as plant population was higher in the highest sowing density and 0.4-m spacing. A greater number of plants are expected when the quantity of seeds per area increases and the spacing between lines decreases because the final plant population is proportional to the highest quantity of seeds used in sowing (Tables 1 and 2).

Plant height is extremely important to appropriate pasture management. In experiment carried out by Antunes et al. (2000), the average height after grazing for the millet was $85 \mathrm{~cm}$. Values close to the height at the beginning of grazing in this study can be observed in the experiment carried out by Fontaneli et al. (2003) with varieties of sorghum hybrid, millet, sudan-grass and teosinte in which the average height of the sorghum hybrid AG 2501C varieties was $1.66 \mathrm{~m}$ and BRS 800 was 1.55 . However, the results for plant height are higher than the ones indicated by Simili et al. (2006), who evaluated sorghum hybrid 1P400 growth and concluded that the best grazing height is between $0.80 \mathrm{~m}$ and $1.0 \mathrm{~m}$ when the percentage of leaf is $50 \%$ and stem is $50 \%$.

Sorghum hybrid is a caespitose grass, presenting a great ability to produce stem that in spite of being nutritive, it is not efficiently consumed in grazing condition when it is higher than $1.20 \mathrm{~m}$. When the stem elongation is intense, animals and pasture are negatively affected. The lowest leaf allowance reduce forage intake, and the highest after grazing residues affect plant regrowth. (Tables 1 and 2). Consequently, the next regrowth is negatively affected inasmuch as the apical meristem is not eliminated, and the lateral and terminals buds are damaged, reducing the production of leaves in the next growth cycles.

The stem diameter of the sorghum hybrid 1P400 was influenced by the sowing density and the grazing cycle (Table 1). Thinner stems were produced when the plant population density was higher as a consequence of the increase in sowing rate. In the second grazing cycle, there was a stem elongation, and the plants were significantly higher with smaller stem diameter.

Table 1 - Stem diameter (mm), height (cm) before and after grazing and plant population (one hundred plant/ha) of sorghum hybrid 1P400 grown in three sowing densities (kg/ha) and two line spacing (m) in the first season (December 2004 to February 2005)

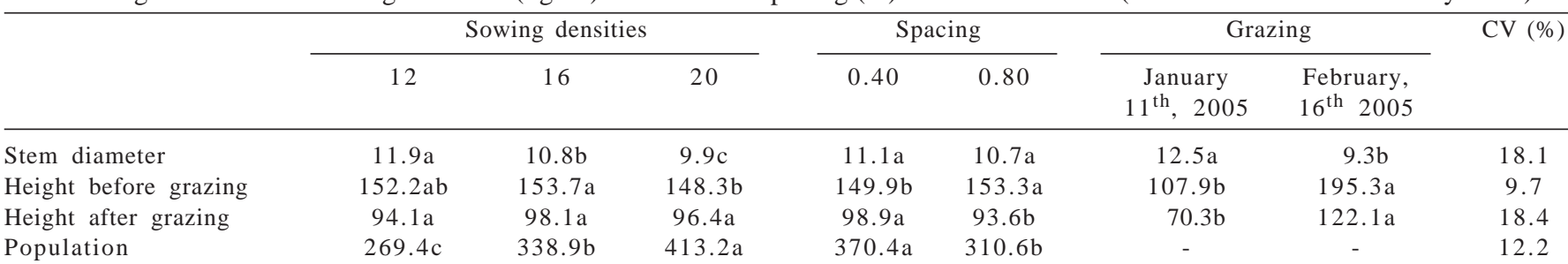

Means within rows with different letters differ $(\mathrm{P}<0.05)$ by Tukey test.

$\mathrm{CV}(\%)=$ coefficient of variation.

Table 2 - Height (cm) before and after grazing and plant population (one hundred plant/ha) of sorghum hybrid 1P400 in three sowing densities (kg/ha) and two line spacing (m) in the second season (March to May 2006)

\begin{tabular}{|c|c|c|c|c|c|c|}
\hline & \multicolumn{3}{|c|}{ Sowing densities } & \multicolumn{2}{|c|}{ Spacing } & \multirow[t]{2}{*}{ CV (\%) } \\
\hline & 12 & 16 & 20 & 0.40 & 0.80 & \\
\hline Height before grazing & $143.0 \mathrm{a}$ & $143.5 \mathrm{a}$ & $136.2 \mathrm{~b}$ & $140.5 a$ & 141.3a & 10.2 \\
\hline Height after grazing & $93.8 \mathrm{a}$ & $93.1 \mathrm{a}$ & $76.7 \mathrm{~b}$ & $83.8 \mathrm{~b}$ & $91.9 \mathrm{a}$ & 19.4 \\
\hline Population & $364.6 b$ & $414.6 b$ & $496.5 \mathrm{a}$ & $462.0 \mathrm{a}$ & $388.4 b$ & 15.7 \\
\hline
\end{tabular}

Means with different letters within rows differ $(\mathrm{P}<0.05)$ by Tukey test.

$\mathrm{CV}(\%)=$ coefficient of variation. 
The higher sowing rate also decreased the stem diameter at $0.40-\mathrm{m}$ spacing as well as at $0.80-\mathrm{m}$ spacing (singular values less than 2) between lines (Figure 2), the same result found by Nogueira et al. (2005) in sorghum hybrid 1P400 research.

In experiment carried out with millet genotypes on different cutting dates, Antunes et al. (2000) observed that the higher the plant, the smaller the stem diameter. Ferreira et al. (2000) reports that there was a decrease in the stem diameter in Sorghum sudanense, a variety of Perennial sorghum, when the cutting was performed later (56 days), and that the increase in height caused a decrease in the stem diameter.

In the first sowing season, forage dry mass production of shoot before grazing and grazing loss pasture were significantly higher in the 0.40 -m spacing. Grazing cycles influenced all the analyzed variables, except leaf dry mass before grazing (Table 3 ).

In a previous experiment, Medeiros et al. (1979) did not find any important difference in forage dry mass when analyzing plant population density (the number of plants per linear meter), as in this experiment. These authors concluded that forage dry mass production of sorghum hybrid 1P400 was 8.51, 9.20, 8.92 and $9.91 \mathrm{t} /$ ha for the densities 10, 20, 30 and 40 plants per linear meter, respectively.

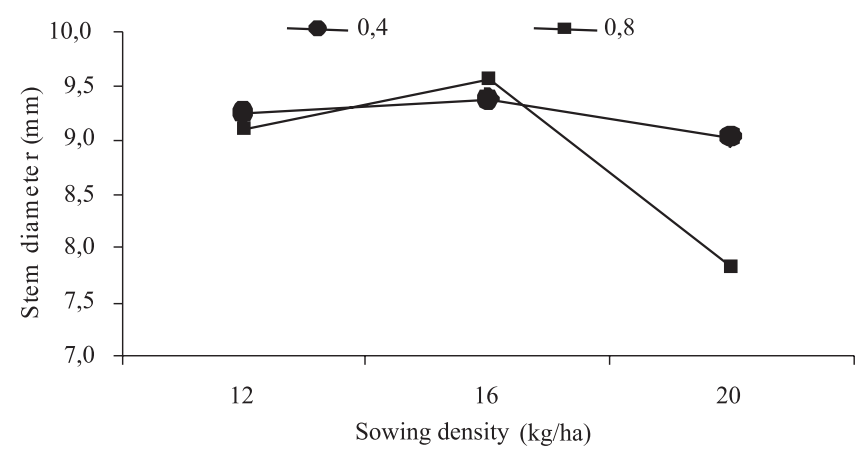

Figure 2 - Stem diameter (mm) of sorghum hybrid 1P400 in three sowing densities (Kg/ha) and two row spacing (meters) in the second season (March to May 2006).
Similar results of dry mass production per cutting were also found in other experiments, such as in the Brazilian central region, in which sorghum hybrid was sown without irrigation in February and produced between 9 and 12 tons of dry mass in three successive cuttings, representing a production of 40 to 60 tons of green forage/ha (Zago, 1997).

According to Fribourg (1995), the sorghum hybrid can be cut during growth for two or up to five times producing $2 \mathrm{t}$ of dry mass per cutting. In a similar experiment carried out in FCAV/UNESP Jaboticabal, Simili et al (2002) obtained an average production of 12 tons DM/ha in a total of five pastures when the species was sown in February $15^{\text {th }}$ in a 30-day resting period.

The increase of forage dry mass production before grazing in the second grazing (Table 3 ) should have occurred due to a higher percentage of stems as a result of the pasture height increase (Table 1). According to Zago (1991), the height of sorghum bicolor is directly related to the forage production and the stem, leaf and panicle proportions.

Although there is no statistical comparison between the sowing seasons, the loss in grazing due to cattle trampling was $43 \%$ higher. Probably, the low rain incidence during this period (Figure 1) must have influenced the growth and development of the sorghum hybrid 1P400, producing thinner stems (Figure 2), less resistant to grazing.

The leaf-stem ratio is an important characteristic of the sward structure, mainly in subtropical grass with rapid stem development (Stobbs, 1973; Silva et al., 1994; Corsi, 2001). This characteristic affects the ingestive behavior of the animals (Stobbs, 1973) and the grazing performance (Silva et al., 1994; Euclides et al., 1999). Similar leaf-stem ratio results were reported by Tomich et al. (2004) in a research in which several sorghum hybrids sown in October and cut at 57 days of growth were evaluated. In this study, forage dry mass production of sorghum hybrid AG 2501C and BRS 800 was 5.8 and 4.0 t/ha with 0.60 and 1.0 leaf-stem ratio, respectively.

The percentage of stems, leaves and dead material for both sowing seasons were neither influenced by sowing

Table 3 - Productive characteristics of sorghum hybrid 1P400 grown in three sowing densities (kg/ha) and two different spacing between lines (meters) in the first season (from December 2004 to February 2005)

\begin{tabular}{|c|c|c|c|c|c|c|c|c|}
\hline & \multicolumn{3}{|c|}{ Sowing densities } & \multicolumn{2}{|c|}{ Spacing } & \multicolumn{2}{|c|}{ Grazing } & \multirow[t]{2}{*}{ CV (\%) } \\
\hline & 12 & 16 & 20 & 0.40 & 0.80 & $\begin{array}{c}\text { January } \\
1^{\text {st }}, 2005\end{array}$ & $\begin{array}{c}\text { February } \\
16^{\text {th }} 2005\end{array}$ & \\
\hline Forage dry matter before grazing (kg DM/ha) & 3.208 & 3.283 & 3.212 & $3.439 \mathrm{a}$ & $3.030 \mathrm{~b}$ & $2.405 b$ & $4.063 a$ & 24.4 \\
\hline Leaf dry matter before grazing (kg DM/ha) & 1.290 & 1.353 & 1.233 & 1.348 & 1.1233 & 1.193 & 1.235 & 27.9 \\
\hline Stem dry matter before grazing (kg DM/ha) & 1.806 & 1.763 & 1.805 & 1.912 & 1.673 & $1.181 \mathrm{~b}$ & $2.503 a$ & 26.3 \\
\hline Leaf/stem ratio & 0.71 & 0.77 & 0.68 & 0.71 & 0,74 & $1.01 \mathrm{a}$ & $0.49 b$ & 23.4 \\
\hline Forage dry matter after grazing (kg DM/ha) & 1.554 & 1.535 & 1.472 & 1.617 & 1.424 & $782 b$ & $2.259 \mathrm{a}$ & 43.6 \\
\hline Forage loss (kg DM/ha) & 779 & 795 & 721 & $891 \mathrm{a}$ & $639 b$ & $601 b$ & $929 a$ & 50.9 \\
\hline
\end{tabular}

Means with different letters within rows differ $(\mathrm{P}<0.05)$ by Tukey test; CV $(\%)=$ coefficient of variation. 
Table 4 - Productive characteristics of sorghum hybrid 1P400 grown at three sowing densities (kg/ha), and two different spacing between lines (meters) in the second season (March to May 2006)

\begin{tabular}{|c|c|c|c|c|c|c|}
\hline & \multicolumn{3}{|c|}{ Sowing density(kg/ha) } & \multicolumn{2}{|c|}{ Spacing between lines (m) } & \multirow[t]{2}{*}{ CV $(\%)$} \\
\hline & 12 & 16 & 20 & 0.40 & 0.80 & \\
\hline Forage dry matter before grazing ( $\mathrm{kg} \mathrm{DM} / \mathrm{ha}$ ) & 3.390 & 3.139 & 2.875 & 3.099 & 3.171 & 19.5 \\
\hline Stem dry matter before grazing ( $\mathrm{kg} \mathrm{DM} / \mathrm{ha}$ ) & 1.987 & 1.902 & 1.662 & 1.841 & 1.858 & 12.4 \\
\hline Leaf/stem ratio & 0.63 & 0.58 & 0.65 & 0.61 & 0.63 & 25.2 \\
\hline Forage dry matter after grazing (kg DM/ha) & 1.087 & 929 & 1.155 & $1.006 \mathrm{~b}$ & $1.108 \mathrm{a}$ & 23.9 \\
\hline
\end{tabular}

Means with different letters within rows differ $(\mathrm{P}<0.05)$ by Tukey test; CV $(\%)=$ coefficient of variation.

density nor by the spacing between lines (Tables 3 and 4). The mean values obtained for the percentage of stem, leaves and dead material were: $86,8.2$, and $5.8 \%$ for the second season, respectively. According to these results, it can be concluded that the grazing animals showed a preference for the leaves. Therefore, stem elongation intensifies forage accumulation, but compromises the canopy structure related to the decreasing in the leaf: stem ratio.

The sowing density and lining spacing specifications are essential to optimize the productivity and to decrease the planting costs of crops like the sorghum hybrid. There are few works on the topic despite of the high commercial value of these crops.

\section{Conclusions}

The dry mass yield of the sorghum hybrid 1P400 is not increased with the sowing density during both sowing seasons, therefore, it is recommended $12 \mathrm{~kg} / \mathrm{ha}$ of seed for the sowing. The 0.80 -m spacing provides lower grazing loss pasture due to cattle stepping.

\section{References}

ANTUNES, R.C.; GONÇALVES, L.C.; RODRIGUES, J.A.S. et al. Características Agronômicas de três genótipos de milheto (CMS-1, CMS-2 e BN-2). In: REUNIÃO ANUAL DA SOCIEDADE BRASILEIRA DE ZOOTECNIA, 37., 2000, Viçosa, MG. Anais... Viçosa, MG: SBZ, 2000. (CD-ROM).

CORSI, M.; MARTHA JÚNIOR, G.B.; NASCIMENTO JUNIOR, D. Impact of grazing management on productivity of tropical grassland. In: INTERNATIONAL GRASSLAND CONGRESS, 19., 2001, São Pedro. Anais... São Pedro, 2001. p.801-806.

DOWAGRO. Novo conceito em nutrição animal, reforma de pastagem e palhada. Available at: <www.dowagro.com.br/ produtos/sementes/sorgo.htm> Accessed on: Apr. 13, 2007.

EMPRESA BRASILEIRA DE PESQUISA AGROPECUÁRIA EMBRAPA. Available at: <www.cnpms.embrapa.br/produtos/ produtos/brs800.html>. Accessed on: Apr. 10, 2007.

EMPRESA BRASILEIRA DE PESQUISA AGROPECUÁRIA EMBRAPA. Centro Nacional de Pesquisa de solos (Rio de Janeiro, RJ). Sistema Brasileiro de Classificação de solos - Brasília: Embrapa Produção de Informação, 1999. 412p.
EUCLIDES, V.P.B.; THIAGO, L.R.L.S.; MACEDO, M.C.M. et al. Consumo voluntário de forragem de três cultivares de Panicum maximum sob pastejo. Revista Brasileira de Zootecnia, v.28, n.6, p.1177-1185, 1999.

FERREIRA, J.J.; CARNEIRO, J.C.; RODRIGUES, J.A. et al. Produção e composição bromatológica do capim Sudão e de seus híbridos (BRS 800 e AG 2501C) com 42 e 56 dias. In: REUNIÃO ANUAL DA SOCIEDADE BRASILEIRA DE Zootecnia, 37., 2000, Viçosa, MG. Anais... Viçosa, MG: SBZ, 2000. (CD-ROM).

FONTANELI, R.S.; FONTANELLI, R.S.; ORTH, R. et al. Produção de Forragem e valor nutritivo de gramíneas anuais de verão semeadas tarde. In: REUNIÃO ANUAL DA SOCIEDADE BRASILEIRA DE ZOOTECNIA, 40., 2003, Santa Maria. Anais... Santa Maria: SBZ, 2003. (CD-ROM).

FRIBOURG, A.H. Summer annual grasses. In: BARNES, F.R.; NELSON, C.J.; COLLINS, M. et al. (Eds.). Forages. 5.ed. Ames: Iowa State University Press, 1995. p.463-472.

MEDEIROS, R.B.; SAIBRO, J.C.; BARRETO, I.L. et al. Efeito do nitrogênio e da população de plantas no rendimento e qualidade do sorgo sordan (Sorghum bicolor (L.) Moench x Sorghum sudanense (Piper) Stapf). Revista da Sociedade Brasileira de Zootecnia, v.8, n.1, p.75-87, 1979.

MORAES, A.; MARASCHIN, E.G. Pressão de pastejo e produção animal em milheto cv. comum. Pesquisa Agropecuária Brasileira, v.23, n.2, p.197-205, 1988.

NOGUEIRA, R.J.; SIMILI, F.F.; LIMA, M.L.P. Efeito de diferentes espaçamentos e densidades de semeadura em sorgosudão na altura das plantas e no diâmetro de colmo. In: REUNIÃO ANUAL DA SOCIEDADE BRASILEIRA DE ZootecniA, 42., 2005, Goiânia. Anais... Goiânia: SBZ, 2005. (CD-ROM).

RESTLE, J.; ROSO, C.; AITA, V. et al. Produção animal em pastagem com gramíneas de estação quente. Revista Brasileira de Zootecnia, v.31, n.3, p.1491-1500, 2002.

RODRIGUES, J.A.S. Utilização de forragem fresca de sorgo (Sorghum bicolor $x$ Sorghum sudanense) sob condições de corte e pastejo. In: SIMPÓSIO DE FORRAGICULTURA E PASTAGENS TEMAS EM EVIDÊNCIA, 1., 2000, Lavras. Anais... Lavras: UFLA, 2000. p.179-201.

SILVA, D.S.; GOMIDE, J.A.; FONTES, C.A.A. et al. Pressão de pastejo em pastagem de capim-elefante anão. 1. Estrutura e disponibilidade de pasto. Revista Brasileira de Zootecnia, v.23, n.2, p.249-257, 1994.

SIMILI, F.F.; REIS, R.A.; MOREIRA, A.L. Avaliação da produção de forragem de sorgo sudão e milheto semeados em diferentes épocas. In: REUNIÃO ANUAL DA SOCIEDADE BRASILEIRA DE ZOOTECniA, 39., 2002, Recife. Anais... Recife: SBZ, 2002. (CD-ROM).

SIMILI, F.F.; LIMA, M.L.P.; NOGUEIRA, R.J. Ácido cianídrico e crescimento do híbrido de sorgo-sudão no outono. In: REUNIÃO ANUAL DA SOCIEDADE BRASILEIRA DE ZOotecniA, 43., 2006, João Pessoa. Anais... João Pessoa: SBZ, p.206. (CD-ROM). 
STATISTICAL ANALYSIS SYSTEM - SAS. SAS/STAT User's guide. Cary: SAS Institute Inc., 2003. (CD-ROM).

STOBBS, T.H. The effect of plant structure on the intake of tropical pastures. I. Variation in the bite size of grazing cattle. Australian Journal of Agricultural Research, v.24, p.809-819, 1973.

TOMICH, T.R.; RODRIGUES, J.A.S.; TOMICH, R.G.P. et al. Potencial forrageiro de híbridos de sorgo com capim-sudão.
Arquivo Brasileiro de Medicina Veterinária e Zootecnia, v.56, n.2, p.258-263, 2004.

ZAGO, C.P. Cultura de sorgo para produção de silagem de alto valor nutritivo. In: SIMPÓSIO SOBRE NUTRIÇÃO DE BOVINOS, 4. 1991, Piracicaba. Anais... Piracicaba: FEALQ. 1991. p.167-217. ZAGO, C.P. Utilização do sorgo na alimentação de ruminantes. Sete Lagoas: EMBRAPA - Centro Nacional de Pesquisas de Milho e Sorgo, 1997. p.9-25. 